[Agr. Biol. Chem., Vol. 31, No. 12, p. 1381 1388, 1967]

\title{
Studies on DL-Alanine Formation by Thermophilic Bacteria
}

\author{
By Takashi Matsumoto, Toshimasa Yano and Koichi Yamada \\ Department of Agricultural Chemistry, \\ The University of Tokyo, Tokyo
}

Received April 27, 1967

\begin{abstract}
During the course of the screening of thermophilic microorganisms, several strains were found to accumulate amino-acids. Of those strains that were isolated from feces source with Bennett medium, one strain was found to produce a large amount of an amino acid. This amino acid was isolated in crystalline form and identified as DL-alanine by IR absorption spectrum, specific rotatory power and elementary analysis. The taxonomic studies were carried out and this strain was identified as Bacillus coagulans. The strain B. coagulans $\mathrm{B}_{9-17}$ produced DL-alanine as much as $1000 \mathrm{mg} / \mathrm{l}$ after 24 hours at $50^{\circ} \mathrm{C}$ in shake culture.

The yield of DL-alanine was increased up to $16.5 \mathrm{~g} / \mathrm{l}$ with some improvements.
\end{abstract}

\section{INTRODUCTION}

Thermophilic bacteria are generally defined as those having optimal temperature for growth between $50^{\circ} \mathrm{C}$ to $65^{\circ} \mathrm{C}$.

Thermophilic bacteria are very interesting not only from industrial standpoint but also from physiological one. Studies pertaining to thermophilic bacteria have been made by many researchers, especially about heat-stable enzymes, ${ }^{1 \sim 51}$ cell components ${ }^{6,7)}$ and nutritional requirements. ${ }^{8 \sim 103}$

However, there appeared almost no studies on the accumulation of metabolic products

1) C. Marsh and W. Militzer, Arch. Biochem. Biophys., 60, 439 (1964).

2) L. L. Campbell and G. B. Manning, J. Biol. Chem., 236, (11), 2952 (1961).

3) L. L. Campbell and G. B. Manning, ibid., 236, (11), 2962 (1961).

4) G. B. Manning, L. L. Campbell and R. J. Foster, ibid., 236, (11), 2958 (1961).

5) L. L. Campbell and P. D. Cleveland, ibid., 236, (11), 2766 (1961).

6) E. R. L. Gaughran, J. Bacteriol., 53, 506 (1947).

7) T. Kobayashi and T. N. Rinker, Arch. Biochem. Biophys., 84, 342 (1947).

8) H. Baker and H. Sobotka, J. Gen. Microbiol, 9, 484 (1953).

9) L. L. Campbell and E. E. Sniff, J. Bacteriol. 65, 267 (1953).

10) H. Baker, O. Frank, B. Black, I. Pasher, H. Hutner and H. Sobotka, Can. J. Microbiol., 6, 556 (1960). and practical use of them except lactic acid fermentation under anaerobic conditions.

This study was carried out to investigate metabolic products of thermophilic bacteria under aerobic conditions, which were scarcely studied in the past.

\section{MATERIALS AND METHODS}

1. Microorganisms. $B$. coagulans $B_{9-17}$, isolated from feces by the authors, was used. $B$. coagulans $\mathrm{B}_{9-17}$ indicated a better growth between $50^{\circ} \mathrm{C}$ and $60^{\circ} \mathrm{C}$, and thus this strain should be called thermophilic, rather than heat resistant. This strain grew well on the yeast extract medium, but did not grow on the medium containing either Polypepton, corn steep liquor or casein hydrolysate, instead of yeast extract.

2. Medium. The accumulation medium used in shake culture contained glucose $50 \mathrm{~g}$, ammonium sulfate $4 \mathrm{~g}$, monobasic potassium phosphate $4 \mathrm{~g}$, magnesium sulfate $0.5 \mathrm{~g}$ and yeast extract $4 \mathrm{~g}$, per liter. One-hundred-milliliter flasks, containing $30 \mathrm{ml}$ each of the medium were sterilized at $115^{\circ} \mathrm{C}$ for 3 minutes.

Before cultivation, $1 \mathrm{~g}$ of sterile $\mathrm{CaCO}_{3}$ was added to the medium in the flask.

3. Cultivation. For the investigation of products, 1 platinum loop of cells grown on the glucose ammonium sulfate agar slant (Table I) for $17 \sim 20$ hours of $50^{\circ} \mathrm{C}$ was inoculated into $30 \mathrm{ml}$ of the 
medium in flask. (Table I)

The culture was incubated at $50^{\circ} \mathrm{C}$ for 24 hours.

4. Paper chromatography. Paper chromatography was employed for the detection of metabolites and was run for 18 hours on Toyo filter paper No. 50 by the ascending method. Solvent systems used are listed in Table II. The spots were visualized by spraying developing reagents.

Table I. Composition of Medium EMPLOYeD FOR THE INVESTIGATION OF PRODUCTS

$\begin{array}{lc}\text { Glucose } & 20.0 \mathrm{~g} \\ \left(\mathrm{NH}_{4}\right)_{2} \mathrm{SO}_{4} & 4.0 \\ \mathrm{KH}_{2} \mathrm{PO}_{4} & 4.0 \\ \mathrm{MgSO}_{4} \cdot 7 \text { aq. } & 0.5 \\ \text { Yeast ext. } & 2.0 \\ \text { Agar agar powder } & 20.0 \\ \text { Dist. Water } & 1000 \mathrm{ml} \\ \text { pH* } & 8.5\end{array}$

* Adjusted to the clesired lebel with $2 \mathrm{~N} \mathrm{NaOH}$ solution.

TABle II. Solvent Systems AND Developing REAGENTS FOR THE DETECTION OF Metabolic Product

Solvent

Reagent

Metabolic Product

(1) BuOH-Acetic Acid B.P.B* Organic Acid -Water $(4: 1: 2)$

Ninhydrin Amino Acid

(2) Phenol Saturated Ninhydrin Amino Acid with Water

* 0.106 Ammoniac Ethyl Alcohol Solution.

\section{RESULT AND DISCUSSION}

\section{Isolation of Microorganisms}

For isolation of thermophilic bacteria from soils and feces, some different media were tested.

The growth of aerobic bacteria was better on modified Czapek-Dox medium (containing $0.6 \%$ of yeast extract $)^{11}$ and Bennett medium. Therefore, these media were used as isolation medium.

Thermophilic bacteria were isolated from field soils and feces of animals in Ueno zoo. These samples were extracted by thoroughly mixing $\mathrm{lg}$ of soil or feces with $10 \mathrm{ml}$ of sterile tap water in $30 \mathrm{ml}$ test tube. One $\mathrm{ml}$ of the extract was plated on the agar medium in a Petri dish and incubated for 24 to 48 hours at $50^{\circ} \mathrm{C}$. Colonies on the plate were fished, purified at $50^{\circ} \mathrm{C}$, and stocked as agar slant culture.

Total 340 strains (Table III) were obtained from soil and feces sources. Of the tested bacteria, strain $\mathrm{B}_{9}-17$ produced a large amount of a single amino acid, where only one ninhydrin-positive spot was detected on the paper chromatogram.

\section{Determination of Metabolic Product}

After 24 hours, the cultured broth was submitted to the paper chromatography. Using glucose as substrate, a single ninhydrin-positive spot was given by the broth of strain $B_{9}-17$.

TABLE III. Number of StRains Isolated

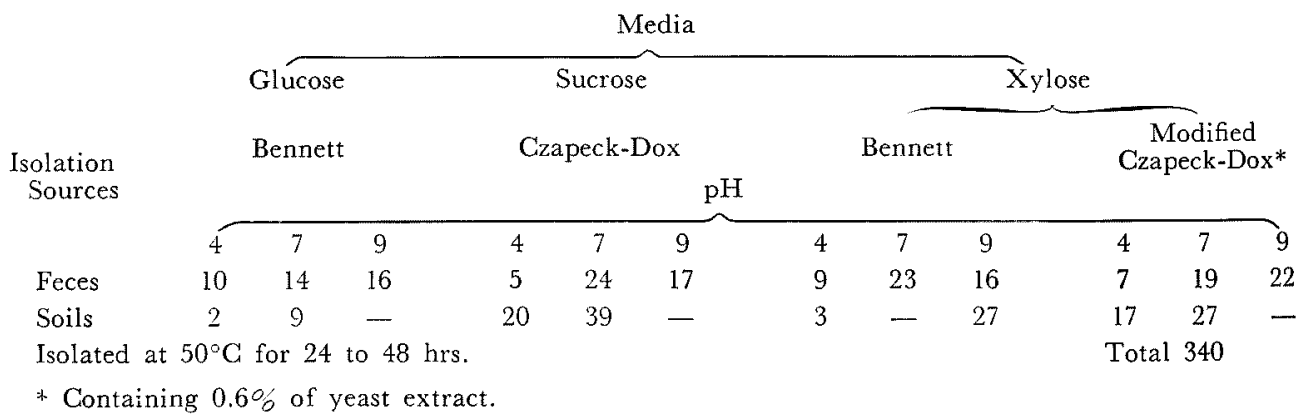

11) E. Küster and E. C. Locci, Arch. Microbiol. 45, 188 (1963). 
Table IV. Paper Chromatogram of Product

Solvent Systems Product $\overbrace{\text { Authentic }}^{R_{F} \text { value* }}$ $n$-BuOH: Acetic acid: Water $(4: 1: 2 \mathrm{v} / \mathrm{v})$ 0.39 Phenol Saturated with Water

0.56

0.56

* After 17 hours at room temperature.

The metabolic product of strain $B_{9}-17$ was assumed to be alanine from $R_{F}$ values of paper chromatogram using two different solvent systems in the ascending technique (Table IV): Amino acid was determined by Yemm-Cocking method. ${ }^{12}$ !

3. Isolation and Identification $\mathrm{DL}$-Alanine as Meatbolic Product

DL-Alanine accumulated in the cultured broth was isolated, purified and identified as described below.

The cells were separated from the cultured broth by centrifugation. Then the supernatant solution was treated with $\mathrm{H}^{+}$type of Amberlite IR-120 and $\mathrm{OH}^{-}$type of Amberlite IRA410 to depicle and with $\mathrm{CH}_{3} \mathrm{COO}^{-}$type of Dowex $1 \times 8$ to adsorb a very small amount of acidic amino acids.

The solution passed through Dowex $1 \times 8$ $\left(\mathrm{CH}_{3} \mathrm{COO}^{-}\right.$type) which was not contaminated with other amino acid as detected in paper chromatogram, was evacuated to dryness. The crude crystals were recrystallized from aqueous ethyl alcohol. The refined crystals were used for IR absorption spectrum, specific rotatory power and elementary analysis. IR absorption spectrum of this compound corresponded completely to that of an authentic specimen. (Fig. 1). Analysis of this amino acid. Found: C, 40.52; H, 7.56; N, 15.79. Calcd. for $\mathrm{C}_{3} \mathrm{H}_{7} \mathrm{NO}_{2}$ : $\mathrm{C}, 40.44 ; \mathrm{H}, 7.92 ; \mathrm{N}, 15.720^{\circ}$. Specific rotatory power indicated that this compound was racemic.

Therefore, this amino acid was identified as DL-alanine.

12) E. W. Yemm and E. C. Cocking, Analyst, 80, 209 (1955).

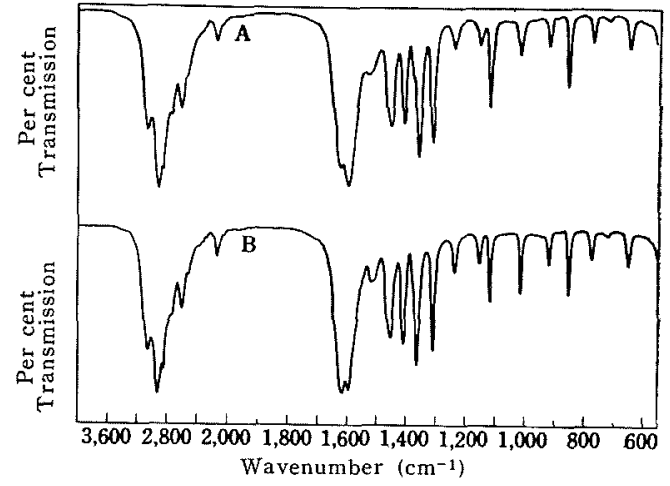

FIG. 1. Infrared Absorption Spectra of the Product.

A: Product R: Authentic DL-Alanine.

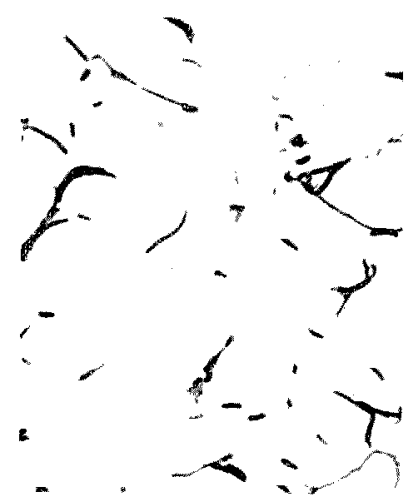

FIG. 2. Microscopic Photograph of Strain $B_{9}-17$ Grown on Nutrient Agar Slant for 48 hours at $50^{\circ} \mathrm{C}$.

\section{Taxonomic Studies of the Strain Isolated}

The results of taxonomic studies are shown in Fig. 2 and Table V. From these results, it was concluded that this strain belongs to $B$. coagulans with reference to Bergey's Manual of Determinative Bacteriology, 7th ed.

It was reported by Baker et al. ${ }^{101}$ that $B$. coagulans generally required methionine and some of them required other amino acids (glutamic acid, alanine, histidne) instead of methionine. However, it was not determined whether the newly isolated strain requires methionine or not. 
Morphological characteristics

Nutrient agar colony

Nutrient agar slant

Glutamate agar slant

Nutrient gelatin stab

B.C.P milk

M.R. test

Product of acetyl methyl carbinol

Hydrolysis of starch

Product of HS

$5 \circ \mathrm{NaCl}$ nutrient broth

Acid production from sugars

\section{TABLE V. TAXONOMIC StUdies}

Rod, 0.6 to 0.8 by 3.0 to 4.0 microns, occurring in filaments.

Spore 0.8 by 1.5 microns, oval to cylindrical, thin-walled, subterminal.

Sporangia not definitely swollen.

Gram positive, motile.

Circular, rough, wrinkled, lobate, yellowish gray, butyrous.

Growth moderate, filiform, flat, wrinkled, yellowish gray.

No growth.

No liquefaction.

Softly coagulate.

Negative.

Negative.

Positve.

Positive.

No growth.

Acid from glucose, fructose and maltose under both aerobic and anaerobic conditions. No acid from glyceroxylose, arabinose, sucrose, lactose and starch.

Glucose, gluconate, citrate, succinate, $p$-hydroxy-benzoate and protocatechuate are not utilized as a sole source of carbon.

Cytochrome oxidase

Negative.

Catalase

Positive.

Grow well between $50^{\circ} \mathrm{C} \sim 55^{\circ} \mathrm{C}$.

No growth at $65^{\circ} \mathrm{C}$.

All the tests were carried out at $50^{\circ} \mathrm{C}$.

5. Some Aspects of DL-Alanine Formation by Strain $B_{9}-17$

1) Influence of different glucose concentrations. It is quite probable that the yield of DL-alanine was influenced by the concentra-

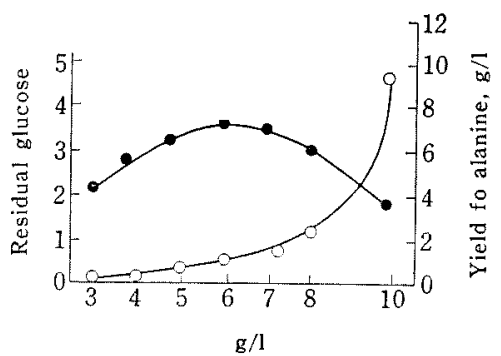

FIG. 3. Influence of Glucose Concentration.

Volume of Medium; $100 \mathrm{ml} / 500-\mathrm{ml}$ flask

Incubation Time; 72 hours

Temperature; $\quad 50^{\circ} \mathrm{C}$

Composition of Medium; $\left(\mathrm{NH}_{4}\right)_{2} \mathrm{SO}_{4} 18 \mathrm{~g}$,

Glucose $50 \mathrm{~g}, \mathrm{KH}_{2} \mathrm{PO}_{4} 4 \mathrm{~g}, \mathrm{MgSO}_{4} .7 \mathrm{aq} .0 .5 \mathrm{~g}$,

Yeast ext. $4 \mathrm{~g}$, Dist. Water $1000 \mathrm{ml}$.

- Yield of alanine

$\bigcirc-\bigcirc$ Residual glucose. tion of glucose in the medium, so that this was investigated using the accumulation medium, so that this was investigated using the accumulation medium. The result is shown in Fig. 3.

The increase in glucose concentration failed to enhance the yield of DL-alanine as shown in Fig. 3. An increase in glucose concentration exceeding $5 \%$ retarded consumption of glucose and resulted in poor DL-alanine formation. The optimal glucose concentration was about $5 \%$.

2) Influence of initial $\mathrm{pH}$ of the medium. In order to investigate the influence of $\mathrm{pH}$ of the culture, $\mathrm{pH}$ of medium was controlled as follows. A range of $\mathrm{pH}$ values from 5.5 to 8.5 in increment of approximately $0.5 \mathrm{pH}$ unit was investigated. (Fig. 4) The initial $\mathrm{pH}$ of the growth medium was adjusted to the desired level, and then was allowed to respond the microbial growth, adding no buffers to the medium.

The medium of $\mathrm{pH} 5.5$ was incubated for 


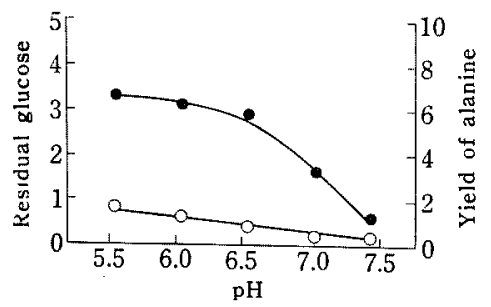

FIG. 4. Influence of Initial $\mathrm{pH}$.

Volume of Medium; $100 \mathrm{ml} / 500-\mathrm{ml}$ flask Incubation Time; 72 hours Temperature; $\quad 50^{\circ} \mathrm{C}$

Composition of Medium; $\left(\mathrm{NH}_{4}\right)_{2} \mathrm{SO}_{4} 18 \mathrm{~g}$,

Glucose $50 \mathrm{~g}, \mathrm{KH}_{2} \mathrm{PO}_{4} 4 \mathrm{~g}, \mathrm{MgSO}_{4} .7 \mathrm{aq} .0 .5 \mathrm{~g}$, Yeast ext. $4 \mathrm{~g}$, Dist. Water $1000 \mathrm{ml}$.

- Yield of alanine

$\bigcirc-\bigcirc$ Residual gucose.

comparing the influence of other $\mathrm{pH}$ values. $\mathrm{pH}$ of the growing culture decreased at early stage of growth to about $\mathrm{pH} 6.0$ to 7.0. The optimal $\mathrm{pH}$ value for formation of DL-alanine was about $\mathrm{pH} 5.5$ to 6.5 , though it was not definitely accurate owing to a slight decline of the $\mathrm{pH}$ value during incubation.

But the consumption of glucose by strain $\mathrm{B}_{9}-17$ was best at $\mathrm{pH}$ 8.5. In contrast, the yield of DL-alanine was little.

3) Influence of incubation temperature. Fig. 5 indicates the influence of incubation temper-

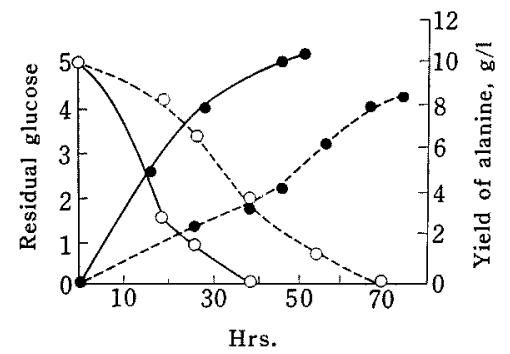

FIG. 5. Influence of Incubation Temperature.

Volume of Medium; $30 \mathrm{ml} / 100-\mathrm{ml}$ flask

Composition of Medium; $\left(\mathrm{NH}_{4}\right)_{2} \mathrm{SO}_{4} 18 \mathrm{~g}$,

$\mathrm{KH}_{2} \mathrm{PO}_{4} 4 \mathrm{~g}, \mathrm{MgSO}_{4} .7$ aq. $0.5 \mathrm{~g}$, Yeast extract

$4 \mathrm{~g}$, Glucose $50 \mathrm{~g}$, Dist. Water $1000 \mathrm{ml}$

Yield of alanine $\left\{\begin{array}{l}\text { at } 56^{\circ} \mathrm{C} \\ \text { at } 50^{\circ} \mathrm{C}\end{array}\right.$

Residual glucose $\left\{\begin{array}{l}\text { at } 56^{\circ} \mathrm{C} \\ \text { at } 50^{\circ} \mathrm{C}\end{array}\right.$ ature on DL-alanine formation and consumption of glucose by $B$. coagulans $\mathrm{B}_{9}-17$. The organism $\mathbf{B}_{9}-17$ was incubated at different temperatures $\left(37^{\circ} \mathrm{C}, 50^{\circ} \mathrm{C}, 56^{\circ} \mathrm{C}, 62^{\circ} \mathrm{C}\right)$, but there was no growth at $37^{\circ} \mathrm{C}$ and $62^{\circ} \mathrm{C}$.

The yield of DL-alanine was higher at $56^{\circ} \mathrm{C}$ than at $50^{\circ} \mathrm{C}$, and further, accumulation of DL-alanine at $56^{\circ} \mathrm{C}$ was initiated at earlier stage than at $50^{\circ} \mathrm{C}$. Therefore, the strain was not only heat-stable, but thermophilic.

4) Influence of different nitrogen sources on DL-alanine formation. In order to compare various nitrogen sources, ammonium sulfate of basal medium was replaced by the equimolar concentration of various nitrogen sources and ten kinds of nitrogen sources were examined for their effect on DL-alanine formation. The results obtained after three days are shown in Table VI. In this table, DLalanine yields in two nitrogen concentrations corresponding to $1.0 \%$ and $2.0 \%$ of $\left(\mathrm{NH}_{4}\right)_{2} \mathrm{SO}_{4}$ are indicated. As shown in Table IV, nitrates and urea were inferior to ammonium salt as to the yield of DL-alanine, and strain $\mathrm{B}_{9}-17$ did not grow on the organic nitrogen medium.

TABLE VI. INFLUENCE OF Nitrogen SOURCES

\begin{tabular}{|c|c|c|c|}
\hline N-Sources & Added & $\begin{array}{c}* \text { Residual } \\
\text { glucose }\end{array}$ & Alanine \\
\hline$\left(\mathrm{NH}_{4}\right)_{2} \mathrm{SO}_{4}$ & $\begin{array}{l}1.000^{\circ} \\
2.00^{\circ}\end{array}$ & $\begin{array}{l}0.00 \% \\
0.00\end{array}$ & $\begin{array}{l}5.41 \mathrm{~g} / \mathrm{l} \\
7.52\end{array}$ \\
\hline $\mathrm{NH}_{4} \mathrm{Cl}$ & $\begin{array}{l}0.90 \\
1.80\end{array}$ & $\begin{array}{l}0.99 \\
1.46\end{array}$ & $\begin{array}{r}12.99 \\
9.97\end{array}$ \\
\hline $\mathrm{NaNO}_{3}$ & $\begin{array}{l}1.40 \\
2.80\end{array}$ & $\begin{array}{l}1.83 \\
2.39\end{array}$ & $\begin{array}{l}\text { trace } \\
\text { trace }\end{array}$ \\
\hline $\mathrm{NH}_{4} \mathrm{NO}_{3}$ & $\begin{array}{l}0.65 \\
1.30\end{array}$ & $\begin{array}{l}1.74 \\
0.47\end{array}$ & $\begin{array}{r}4.53 \\
11.84\end{array}$ \\
\hline Urea & $\left\{\begin{array}{l}0.50 \\
1.00\end{array}\right.$ & $\begin{array}{l}2.33 \\
2.33\end{array}$ & $\begin{array}{l}\text { trace } \\
\text { trace }\end{array}$ \\
\hline $\mathrm{NH}_{4}$-acetate & $\left\{\begin{array}{l}1.10 \\
2.20\end{array}\right.$ & $\begin{array}{l}5.00 \\
5.00\end{array}$ & $\begin{array}{l}0.00 \\
0.00\end{array}$ \\
\hline $\mathrm{NH}_{4}$-phosphate & $\left\{\begin{array}{l}1.90 \\
3.80\end{array}\right.$ & $\begin{array}{l}5.00 \\
5.00\end{array}$ & $\begin{array}{l}0.00 \\
0.00\end{array}$ \\
\hline $\mathrm{NH}_{4}$-lactate & $\begin{array}{l}1.50 \\
3.00\end{array}$ & $\begin{array}{l}2.57 \\
3.53\end{array}$ & $\begin{array}{l}2.77 \\
2.10\end{array}$ \\
\hline Peptone & $\begin{array}{l}1.30 \\
2.60\end{array}$ & $\begin{array}{l}5.00 \\
5.00\end{array}$ & $\begin{array}{l}0.00 \\
0.00\end{array}$ \\
\hline
\end{tabular}

* Residual glucose after 70 hour's incubation at $50^{\circ} \mathrm{C}$.

Initial concentration was $5 \%$.

Volume of the medium was $100 \mathrm{ml} / 500$-ml flask. 
Of the nitrogen sources tested, ammonium sulfate, ammonium chloride and ammonium nitrate were good for the yield of DL-alanine. The highest yield of DL-alanine was obtained with ammonium chloride, which however retarded the consumption of glucose remarkably, in contrast with a little effect of ammonium sulfate in this respect.

5) Influence of the concentration of nitrogen source. In order to find the suitable concentration of nitrogen source in the medium, ammonium sulfate and ammonium chloride were used as nitrogen source for bL-alanine accumulation.

The result is presented in Fig. 6. As obviously seen from the figure influence of the

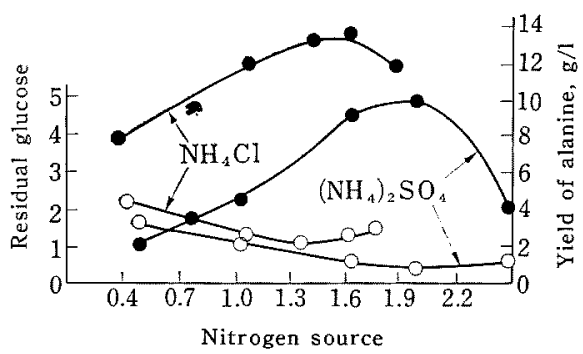

FIG. 6. Influence of Nitrogen Concentration.

\begin{tabular}{|c|c|}
\hline Temperature; & $56^{\circ} \mathrm{C}$ \\
\hline Incubation Time; & $\begin{array}{l}45 \text { hours (using }\left(\mathrm{NH}_{4}\right)_{2} \mathrm{SO}_{4} \text { as } \\
\text { nitrogen source) } \\
50 \text { hours (using } \mathrm{NH}_{4} \mathrm{Cl} \text { as nitro- } \\
\text { gen source) }\end{array}$ \\
\hline $\begin{array}{l}\text { Volume of Mediur } \\
\text { Composition of } \mathrm{M} \\
\text { Glucose } 50 \mathrm{~g}, \mathrm{~K} \\
\text { Yeast ext. } 4 \mathrm{~g}, \mathrm{I}\end{array}$ & $\begin{array}{l}\mathrm{m} ; \quad 30 \mathrm{ml} / 100-\mathrm{ml} \text { flask } \\
\text { Iedium except nitrogen source; } \\
\mathrm{KH}_{2} \mathrm{PO}_{4} 4 \mathrm{~g}, \mathrm{MgSO}_{4} \cdot 7 \mathrm{aq} .0 .5 \mathrm{~g} \text {, } \\
\text { Dist. Water } 1000 \mathrm{ml} .\end{array}$ \\
\hline $\begin{array}{l}\text { Glucose. } \\
\text { Gield of }\end{array}$ & Alanine $\bigcirc-\bigcirc$ Residual \\
\hline
\end{tabular}

concentration of nitrogen source was very remarkable and the optimal concentration for the yield of DL-alanine was about $1.3 \% \mathrm{w} / \mathrm{v}$ for ammonium chloride and about $2.0 \%(\mathrm{w} / \mathrm{v})$ for ammonium sulfate. The highest yield of DL-alanine was obtained with $1.3 \%$ of ammonium chloride and it was $16.5 \mathrm{~g}$ per liter. About $40 \%(\mathrm{w} / \mathrm{v})$ of the consumed glucose was converted into DL-alanine.
6) Influence of oxygen supply. At $55^{\circ} \mathrm{C}$, oxygen will be dissolved in water about a half comparing the case of at $30^{\circ} \mathrm{C}$. In order to investigate the influence of oxygen supply on the formation of DL-alanine, the shake culture experiments were performed under the different conditions by varying the volume of the medium in flask shaken at 140 recip./min with $50 \mathrm{~mm}$ stroke.

Judging from the results shown in Fig. 7,

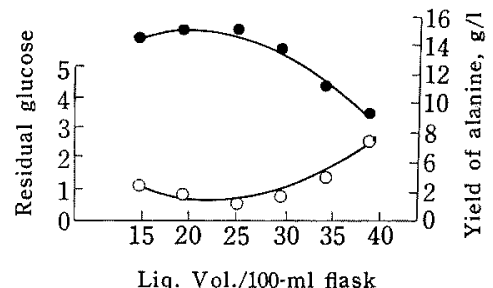

FIG. 7. Influence of Oxygen Supply.

Temperature; $\quad 56^{\circ} \mathrm{C}$

Incubation Time; 50 hours

Composition of Medium; $\mathrm{NH}_{4} \mathrm{Cl} 13.5 \mathrm{~g}$, Glucose $50 \mathrm{~g}$,

$\mathrm{KH}_{2} \mathrm{PO}_{4} 4 \mathrm{~g}, \mathrm{MgSO}_{4} .7 \mathrm{aq} .0 .5 \mathrm{~g}$, Yeast ext. $4 \mathrm{~g}$, Dist. Water $1000 \mathrm{ml}$

- Yield of Alanine $\mathrm{O}-\mathrm{O}$ Residual Glucose.

the influence of oxygen supply was not remarkable. However, it was considered that oxygen supply was a controlling factor; excess of this seemed to be rather inhibitory for DLalanine formation.

7) Influence of $\mathrm{KH}_{2} \mathrm{PO}_{4}$ and $\mathrm{MgSO}_{4} \cdot 7$ aq. concentrations on DL-alanine formation. It is quite probable that the fermentation products are generally influenced by the concentration of $\mathrm{KH}_{2} \mathrm{PO}_{4}$ and $\mathrm{MgSO}_{4} \cdot 7$ aq., so that the influence of these inorganic salts is to be studied. The results obtained in this respect are shown in Fig. 8 and Fig. 9. In case of $\mathrm{KH}_{2} \mathrm{PO}_{4}$, the best result was obtained at the concentration of $0.4 \%$ in both the media of $\left(\mathrm{NH}_{4}\right)_{2} \mathrm{SO}_{4}$ and of $\mathrm{NH}_{4} \mathrm{Cl}$, whereas the concentration of $\mathrm{KH}_{2} \mathrm{PO}_{4}$ exceeding $0.4 \%$ made the growth unstable. On the other hand, increase of $\mathrm{MgSO}_{4} \cdot 7$ aq. concentration in the medium 


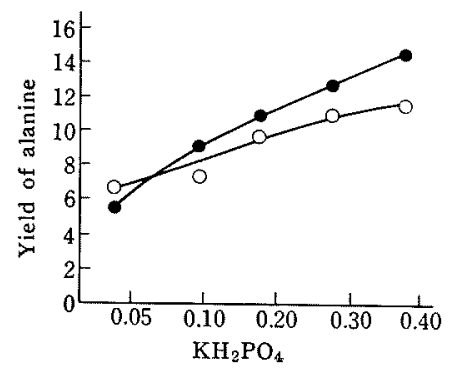

FIG. 8. Influence of Concentration of $\mathrm{KH}_{2} \mathrm{O}_{4}$.

Incubation temperature; $56^{\circ} \mathrm{C}$

Nitrogen sources: $\quad 1.35 \%$ of $\mathrm{NH}_{4} \mathrm{Cl}$ or

$2.0 \%$ of $\left(\mathrm{NH}_{4}\right)_{2} \mathrm{SO}_{4}$

of medium; $25 \mathrm{ml} / 100-\mathrm{ml}$ flask

Composition of medium except nitrogen and $\mathrm{KH}_{2} \mathrm{PO}_{4}$;

Glucose $50 \mathrm{~g}, \mathrm{MgSO}_{4} .7 \mathrm{aq} .0 .5 \mathrm{~g}$, Yeast ext. $4 \mathrm{~g}$,

Dist. Water $1000 \mathrm{ml}$.

Yield of alanine

- (using $\mathrm{NH}_{4} \mathrm{Cl}$ as nitrogen source)

$\mathrm{O}-\mathrm{O}$ (using $\left(\mathrm{NH}_{4}\right) \mathrm{SO}_{4}$ as nitrogen source).

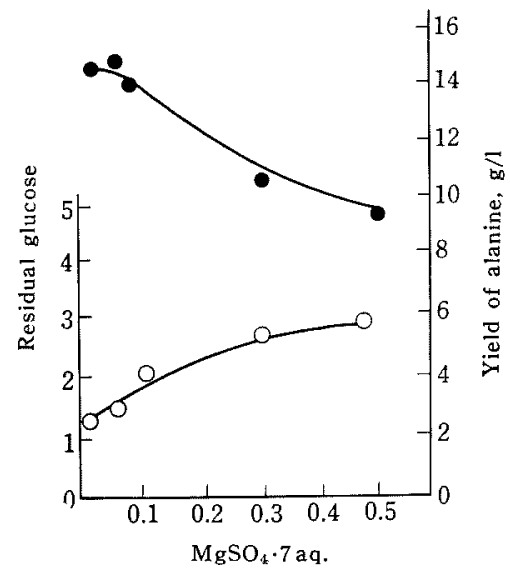

FIG. 9. Influence of Concentration of $\mathrm{MgSO}_{4} .7$ aq.

$\begin{array}{ll}\text { Incubation time; } & 50 \text { hours } \\ \text { Temperature; } & 56^{\circ} \mathrm{C}\end{array}$

Volume of medium; $25 \mathrm{ml} / 100-\mathrm{ml}$ flask

Composition of medium except $\mathrm{MgSO}_{4} .7$ aq.,

$\mathrm{NH}_{4} \mathrm{Cl} 13.5 \mathrm{~g}$, Glucose $50 \mathrm{~g}, \mathrm{KH}_{2} \mathrm{PO}_{4} 4 \mathrm{~g}$, Yeast ext. $4 \mathrm{~g}$, Dist. Water $1000 \mathrm{ml}$.

- Yield of alanine

O-O Residual glucose.

was rather inhibitory.

8) Culture under optimal conditions. The most favourable culture conditions (Table VII)
Table ViI. Optimal Medium and Condition

Glucose

$\mathrm{NH}_{4} \mathrm{Cl}$

$50.0 \mathrm{~g}$

$\mathrm{KH}_{2} \mathrm{PO}_{4}$

13.5

$\mathrm{MgSO}_{4} .7 \mathrm{aq}$

4.0

Yeast ext.

0.5

4.0

Dist. Water

Volume of the medium

$1000 \mathrm{ml}$

Incubation temperature

$25 \mathrm{ml} / 100$-ml flask $56^{\circ} \mathrm{C}$

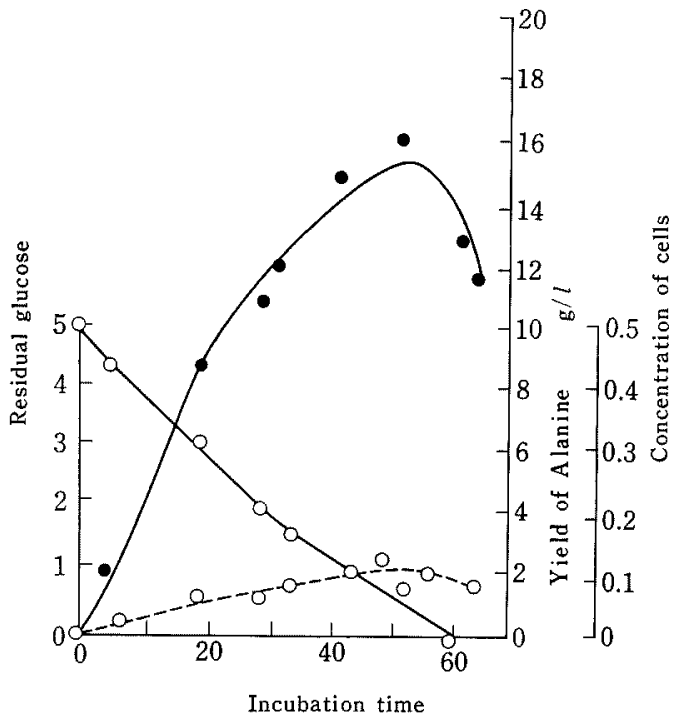

FIG. 10. Culture under Optimal Condition Condition as Table VII.

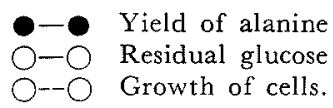

for DL-alanine accumulation were investigated by the fermentation experiments. The results are shown in Fig. 10. Glucose was almost exhaustively consumed in 65 hours and the rate of conversion to DL-alanine attained more than $40 \% \mathrm{w} / \mathrm{v}$. The maximum yield of $\mathrm{DL}-$ alanine was attained in 56.5 hours culture and residual glucose was about $1 \%$.

\section{SUMMARY}

1. One strain of thermophilic bacillus, which produced an amino acid, was isolated 
from a feces source with Bennett medium.

2. This strain was identified to Bacillus coagulans.

3. The amino acid produced by this strain was identified as DL-alanine.

4. The cultural conditions were investigated, and ammonium chloride was favourable for the amino acid production.
Acknowledgement. We wish to express our sincere gratitude to Dr. K. Komagata of the Central Research Laboratory of Ajinomoto Co., Inc., for his help in the taxonomic studies. We also wish to thank Mr. N. Fukuda and Mr. A. Awata of Ueno Zoo for the supply of feces sources used in this work. 